\title{
Clinical approach to canine vaginitis
}

\author{
Abordagem clínica da vaginite canina
}

\author{
Marcos Cezar Sant'Anna ${ }^{1}$; Andrei Kelliton Fabretti ${ }^{1}$; Maria Isabel Mello Martins ${ }^{2 *}$
}

\begin{abstract}
Vaginitis is a rare disease in adult female dogs. However, knowledge regarding this illness is important because, if secondary to reproductive tract anomalies that go uncorrected, it can cause ascending uterine infections and, consequently, subfertility or even infertility. Usually, these infections are caused by Enterobacter or microorganisms from the urogenital inferior system, such as Staphylococcus spp, Streptococcus spp, Escherichia coli, Proteus spp, Pseudomonas aeruginosa, Pasteurella, etc. In some cases, vaginitis may be caused by primary infections with Brucella canis, which is zoonotic, or by canine herpesvirus; both of these agents have the potential to cause reproductive failure. The disease can occur in any age, breed or ovarian condition and can be identified by vaginal cytology, vaginoscopy and culture of vaginal secretions. The most common clinical signs are erythema of the vaginal mucous, vaginal discharge, pollakiuria, licking of the vulva and attraction of male dogs, independent of the phase of the estrous cycle. This disease is generally self-limiting, and the treatment, when necessary, consists of antibiotic therapy, vaginal cleaning with antiseptic and, eventually, surgical correction of predisposing abnormalities.
\end{abstract}

Key words: Inflammation/infection vaginal, reproduction, bitch

\section{Resumo}

A vaginite é uma afecção rara em cadelas adultas. É uma causa importante de subfertilidade ou infertilidade, quando secundária à anomalias do trato reprodutivo. Normalmente, são causadas por enterobactérias ou pela microbiota do sistema urogenital inferior, tais como Staphylococcus spp, Streptococcus spp, Escherichia coli, Proteus spp, Pseudomonas aeruginosa, Pasteurella, entre outras. Em alguns casos, pode ser primária como infecções por Brucella canis, a qual é uma zoonose ou herpesvírus canino, importante causa de falhas reprodutivas. A afecção acomete fêmeas de qualquer idade, raça ou condição ovariana. Os sinais clínicos envolvem mucosa vaginal hiperêmica, corrimento vulvar, polaquiúria, lambedura vulvar, e atração de machos independente da fase do ciclo estral. Pode ser diagnosticada por citologia vaginal, vaginoscopia e cultura da secreção. A enfermidade, muitas vezes, é autolimitante e o tratamento, quando necessário, é realizado com infusão vaginal de antissépticos ou antibióticos e, eventualmente, correção cirúrgica de anormalidades predisponentes.

Palavras-chave: Inflamação/infecção vaginal, reprodução, cadela

\footnotetext{
${ }^{1}$ Mestrando(s) do Programa de Pós-Graduação em Ciência Animal, área de Sanidade Animal, Universidade Estadual de Londrina,UEL, Londrina, PR. E-mail: santannamarcos@bol.com.br; fabretti@uel.br

${ }^{2} \mathrm{MSc}, \mathrm{PhD}$. Prof ${ }^{\mathrm{a}}$ de Teriogenologia de Animais de Companhia. Dept ${ }^{\mathrm{o}}$ de Clínicas Veterinárias, UEL, Londrina, PR. E-mail: imartins@uel.br

* Author for corespondence
} 


\section{Introduction}

The vagina is a tubular structure extending from the junction of the vaginal vestibule to the cervix. In bitches, the vagina is relatively long, with an average length of $10 \mathrm{~cm}$ in medium-sized females (SILVA; SILVA; CARDOSO, 2002). This peculiarity makes the examination of the vagina difficult when performed without instruments of adequate size (PURSWELL, 2004). The anterior portion of the vagina is narrow $(5-7 \mathrm{~mm})$, which makes inspection of the cervix difficult, even with an endoscope, if it is not appropriate to the size of the animal (SILVA; SILVA; CARDOSO, 2002; PURSWELL, 2004).

The vaginal vestibule is shared by the urinary and reproductive tracts (SILVA; SILVA; CARDOSO, 2002; HAFEZ; HAFEZ, 2004; PURSWELL, 2004). From the vaginal junction vestibule, there is a downward inclination toward the vestibule that ends in the ventral commissure of the vulva, and the urinary meatus is in the vestibule floor, approximately $5 \mathrm{~mm}$ distal to the vaginal junction vestibule (SILVA; SILVA; CARDOSO, 2002; HAFEZ; HAFEZ, 2004).

Vaginitis is an inflammation of the vagina and vaginal vestibule, which may or may not have an infectious cause (JOHNSON, 1991; HAFEZ; HAFEZ, 2004). It can occur at any age, breed or ovarian condition and is suggestive of anatomical abnormalities of the reproductive tract, which can often be corrected with surgical repair (SODERBERG, 1986; JOHNSTON; KUSTRITZ; OLSON, 2001; JOHNSON, 2009).

Study of this disease is important because knowledge of the characteristics of the disease allows diagnosis, identification of the primary causes and correction, when possible. When the primary cause of the disease is not corrected, recurrence is frequent.

This study aimed to review information about the etiology, clinical features, diagnostic methods, reproductive losses, treatment and peculiarities of canine vaginitis in young and adult animals, focusing on the etiological causes.
The causes of canine vaginitis are variable and can be classified as primary, in the case of infection with canine herpes virus type I (HVC I) and Brucella canis, or secondary in cases of immature reproductive tract diseases, immunosuppressive drugs (the hormone androgen and zinc intoxication), or prophylactic antibiotics, which reduce bacterial microbiota and allow the overgrowth of pathogenic strains (JOHNSON, 2009). Additional causes include hyper- or hypoestrogenism, urinary tract infection or urinary incontinence, genital infections such as pyometra, metritis or uterine stump abscess, vaginal trauma, chemical irritation due to urovagina, mechanical irritation caused by foreign bodies or tumors, anatomic abnormalities of the genitourinary system and vaginal atrophy after castration (SODERBERG, 1986; JOHNSTON; KUSTRITZ; OLSON, 2001; PURSWELL, 2004; TILLEY; SMITH, 2007; JOHNSON, 2009).

\section{Bacterial Vaginitis}

Bacterial vaginitis is usually secondary to hormonal disorders, nutritional deficiencies, prophylactic use of antibiotics, or poor sanitary conditions that predispose to increased bacterial proliferation (HASHIMOTO et al., 2002). It is usually caused by enterobacteria or by the microbiota of the lower urogenital system, including Staphylococcus spp, Streptococcus spp, Proteus mirabilis and vulgaris, Pseudomonas aeruginosa, Haemophilus, Escherichia coli and Pasteurella haemolytica (TILLEY; SMITH, 2007; AVILA et al., 2008). Klebsiella sp., Shigella sp. and Citrobacter sp can be found less frequently (AVILA et al., 2008)

Hashimoto et al. (2002) identified the main bacteria that cause vaginitis: coagulase-positive Staphylococcus (27.28\%), Proteus spp (18.18\%), Streptococcus spp (18.18\%), coagulase-negative Staphylococcus $(9.09 \%)$, E. coli $(9.09 \%)$ and coagulase-positive Staphylococcus associated with Streptococcus spp (18.18\%). Pasteurella, Pseudomonas, Mycoplasma and Chlamydophila are 
also common causes (JOHNSTON; KUSTRITZ; OLSON, 2001). Often, immature bitches have greater numbers of coagulase-positive Staphylococcus (FELDMAN; NELSON, 1996). These bacterial agents can cause local infections in the vagina, as well as reproductive damage, infertility, embryonic death or abortion (HOLLETT, 2006).

Vaginitis caused by B.canis infection will be discussed hereafter.

\section{Vaginitis caused by Brucella canis}

Vaginitis due to B.canis infection is considered primary (JOHNSTON; KUSTRITZ; OLSON, 2001) and important in the differential diagnosis of dogs presenting with lesions and/or vaginal secretions and a history of reproductive problems. In general, Brucellae commonly infect the reproductive organs of males and females that have reached sexual maturity, and each species of Brucella tends to infect a specific animal species (QUINN, 2004).

B.canis is a small, unencapsulated gram-negative coccobacillus that is unable to move or form spores. These bacteria are facultative intracellular parasites (PESSEGUEIRO; BARATA; CORREIA, 2003). The major transmission route is venereal; however, additional modes of transmission include vaginal discharge after abortion, milk from infected bitches, blood transfusions, vaginoscopy, artificial insemination and contaminated needles (BROWN; PIETZ; RANGER, 1975).

These bacteria gain entry through ingestion or mucous membrane exposure of the host (genital, oronasal and/or conjunctival). Transmission through skin injuries is also possible (CFSPH, 2009). After penetrating the tissue, the pathogen is phagocytosed and transported to regional lymph nodes, remaining within macrophages. Inhibition of the lysosomal function of leukocytes is the main intracellular defense mechanism of Brucella (QUINN, 2004). The bacterium targets lymphoid tissues and steroiddependent organs like the uterus, vestibulovaginal canal, placenta, testis, epididymis and prostate (GREENE; CARMICHAEL, 2006).

Several studies have assessed the prevalence of canine brucellosis in different regions of Brazil, where the differences found usually depend on the population studied and the diagnostic test employed.

In Alfenas, in the state of Minas Gerais, the prevalence of $B$. canis using the agar gel immunodiffusion (AGID) screening test was $14.2 \%$ $(90 / 635)$, but only $2.8 \%$ was confirmed by the agglutination test with 2 - mercaptoethanol (SAL 2 - MET) (ALMEIDA, et al., 2004). In the region of Botucatu in the state of São Paulo, the prevalence was $0.84 \%$ using population and diagnostic test similar to that used in the previous study (MORAES et al., 2002). Keid et al. (2004) studied the prevalence of brucellosis in 12 commercial kennels in São Paulo state, where the seroprevalence by AGID ranged from 40 to $77 \%$. When blood culture analysis was used instead, the prevalence ranged from 2.7 to $54.54 \%$.

There are few studies about the human prevalence of brucellosis in Brazil. Spinola and Costa (1972) detected a brucellosis seroprevalence of $10.8 \%$ in the workers at a slaughterhouse in Salvador Bahia. In São Paulo, serum samples were analyzed from 330 humans from a clinical laboratory by SAL, using specific agglutinins for B. canis, and a prevalence of $1.21 \%$ was found (LARSSON, 1980). This result highlights the importance of the diagnosis and prevention of canine brucellosis and its zoonotic potential.

\section{Viral vaginitis}

Viral vaginitis is caused by herpes virus type I (HVC I) infection, which only infects domestic dogs, wild dogs and cell cultures (COMERCIO, 2004).

Several studies have shown a high prevalence of HVC I in various populations. Reading and Field (1998) evaluated 325 dogs brought to the Cambridge School of Veterinary Medicine for medical care and 
routine surgery and found an average seroprevalence of $80 \%$.

Another seroepidemiological study in South Africa evaluated 328 canines older than one year of age from 38 reproduction kennels. Seropositivity was found in $22 \%$ of the samples, and seventeen kennels $(45 \%)$ had at least one positive sample (NOTHLING et al., 2007). When comparing the prevalence of HCV I in kennels with and without reproductive problems, Dahlbom et al. (2009) noted significantly higher titers in kennels with reproductive problems, where $100 \%$ of the samples had titers considered positive, compared to $62 \%$ positivity in the kennels without reproductive problems.

\section{Clinical Signs and Diagnosis}

Clinical signs involve mucopurulent or purulent mucoid vulvar discharge, which is rarely bloody and is present in $90 \%$ of bitches with vaginitis. Symptoms including pollakiuria, licking the vagina and attraction of males, regardless of the cycle phase, are observed in $10 \%$ of cases (Figure
1) (FELDMAN; NELSON, 1996; JOHNSTON; KUSTRITZ; OLSON, 2001; JOHNSON, 2009; MUSHTAQ, 2008).

The digital inspection of the vagina is important to evaluate the vaginal vestibule, the urethral crest and the vestibulovaginal junction, and it is useful for identifying persistent hymen, stenosis, or vaginal anomalies or tumors, although the size of the animal can limit the extent of the examination (PURSWELL, 2004; TILLEY; SMITH, 2007).

The evaluation of vaginal cytology can identify inflammatory cells, neoplastic cells, blood or feces beyond the phase of the estrous cycle (TILLEY; SMITH, 2007). When neutrophils are shown in large quantities, it is important to differentiate of the diestrus, phase of the estrous cycle that shows lots of these inflammatory cells, which in this case are not degenerate. During vaginal infections, many neutrophils are in the process of degeneration, which can occur in the presence or absence of bacteria. The chronicity of the process culminates with an increase of lymphocytes and macrophages. To locate the infection, additional tests such as vaginal endoscopy may be required (PURSWELL, 2004).

Figure 1. Animal with vaginitis. Note the vulvar edema secondary to vaginal licking and pustules in the vulvar region.

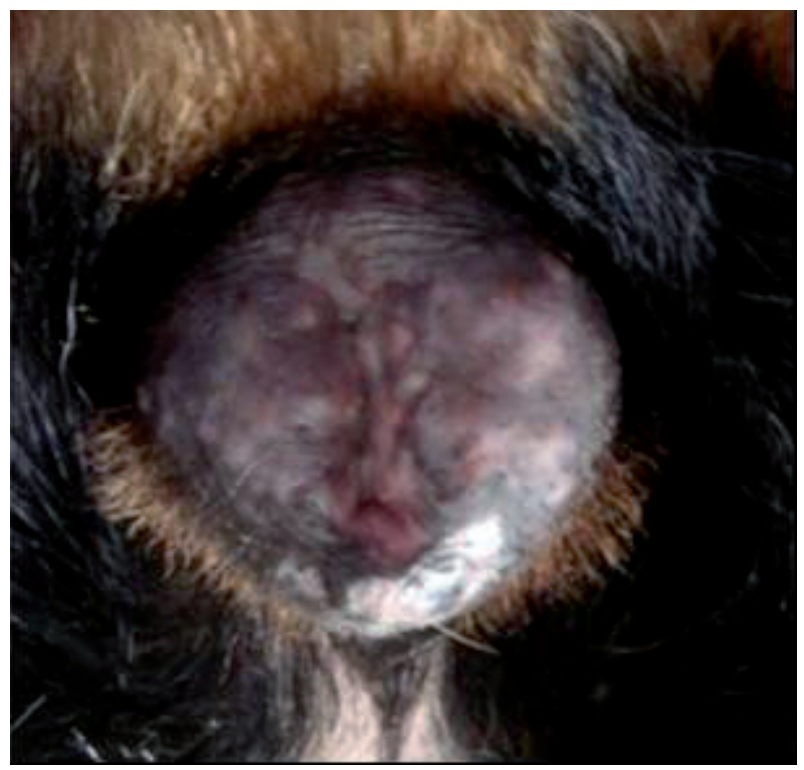

Source: Elaboration of the authors. 
Ideally, vaginoscopy should be performed with an endoscope, proctoscope, cystoscope or other optic fiber device of at least $15 \mathrm{~cm}$ in length. During the evaluation, it is necessary to inflate the vagina with air. Rigid equipment provides a better sense of the vagina, as it can easily overcome the natural collapse of the vaginal folds; however, flexible endoscopes can be used. The diameter should be $5 \mathrm{~mm}$ or less to allow thorough inspection of the anterior vagina and cervix. Vaginoscopy is generally performed with the animal held stationary, without the need for anesthesia, but in some cases there is pain due to local inflammation, and sedation may be required. Examination can reveal anatomic abnormalities, tumors, foreign bodies, hematomas, abscesses and mucosal changes such as hyperemia, vesicles, ulcers and hyperplasia of lymphoid follicles (Figure 2). It can also allow the observation of exudate, in which case it is essential to determine if the origin is uterine, vaginal or vestibular (PURSWELL, 2004; TILLEY; SMITH, 2007).

Contrast radiography is especially useful in cases involving obstructive vaginal neoplasia, foreign bodies, vestibule-vaginal or rectovaginal stenosis. Ultrasonography helps in identifying intraluminal vaginal neoplasias, and the distension of the vagina with saline solution aids in this visualization (TILLEY; SMITH, 2007). Vaginal biopsy may suggest the nature of any injuries such as neoplasias, inflammation, or viral/bacterial infections (JOHNSON, 2009).

Figure 2. Animal with vaginitis caused by coagulase-negative Staphylococcus. Note the hyperemia of the vulvar mucosa and vaginal vestibule, covered with pustules and purulent exudate (arrows).

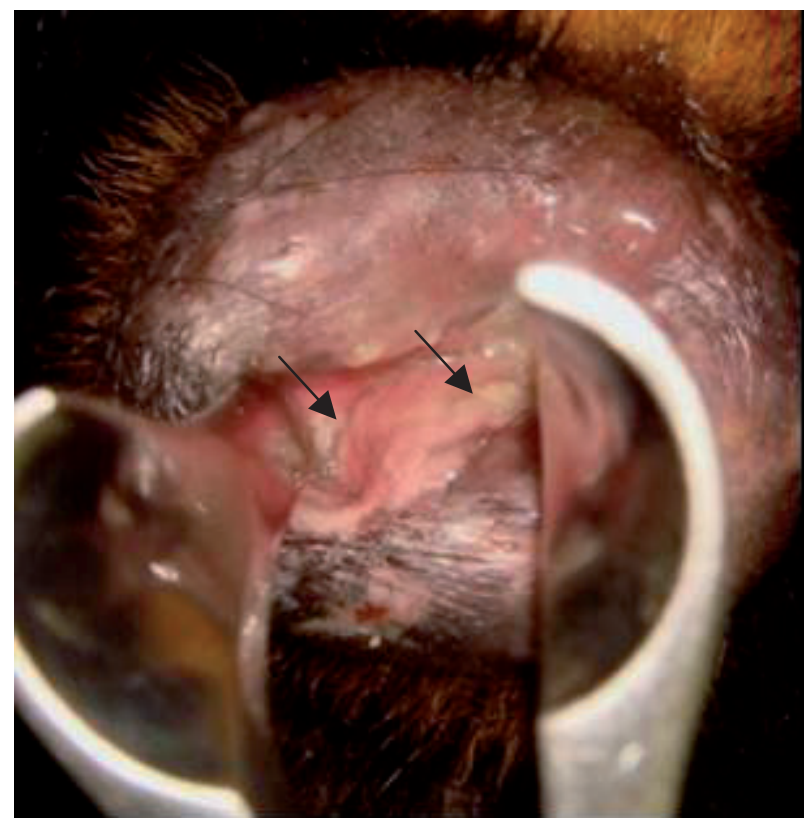

Source: Elaboration of the authors.

\section{Bacterial vaginitis}

The most common clinical signs of bacterial vaginitis are mucopurulent or purulent vulvar discharge, pollakiuria, licking the vagina and the attraction of males regardless of the estrous cycle. There is usually not systemic involvement (JOHNSTON; KUSTRITZ; OLSON, 2001).

Culture and cytological analysis of vaginal discharge can be performed if no specific alterations of the vagina can be identified (PURSWELL, 
2004). Urinalysis and urine culture are desirable, as infections or tumors of the urinary tract may initially be confused with vaginitis (FELDMAN; NELSON, 1996).

The results from bacterial culture should be interpreted carefully. Bacteria isolated from bitches with vaginitis are generally similar to the vaginal microbiota in number and species (RONSEE et al., 2004; JOHNSON, 2009; MUSHTAQ, 2008). The growth of opportunistic aerobic pathogens, anaerobic bacteria and mycoplasma on the culture material of an asymptomatic animal does not denote infection. However, in symptomatic animals, if there is overgrowth of a single organism (more than 100 colony forming units), this organism should provisionally be considered responsible for the infection (PURSWELL, 2004; RONSEE et al., 2004; VERSTEGEN; DHALIWAL; VERSTEGENONCLIN, 2008).

The culture and sensitivity test results are more important in determining the proper antibiotic to be used than to diagnose vaginitis (JOHNSON, 2009).

\section{Vaginitis caused by Brucella canis}

The clinical sign of vaginitis reported most often by owner is miscarriage during the final third of gestation. However, brucellosis may result in fetal death or resorption in the first third of pregnancy. After abortion, an extended viscous serosanguinous vaginal discharge that may last 1-6 weeks is commonly observed. This discharge contains a large number of bacteria, which, due to its zoonotic potential, can serve as a source of infection to other dogs and humans (HOLLETT, 2006). Because of these clinical signs, brucellosis is considered an important differential diagnosis for dogs presenting vaginal discharge, infertility, abortions and vaginitis.

The diagnosis of canine brucellosis should be performed based on patient history, clinical signs, and serological screening associated with bacterial isolation from blood or contaminated tissue (GREENE; CARMICHAEL, 2006).
Serological diagnosis can be performed using the following techniques: Rapid Slide Agglutination Test (RSAT), SAL and AGID ELISA. The diagnosis is confirmed by the isolation of $B$. canis from positive dogs by serological screening. Blood culture is the preferred method because it allows an early diagnosis (from ten days after infection). However, polymerase chain reaction (PCR) has been studied for the definitive diagnosis of $B$. canis and shows a diagnostic performance similar to that of microbiological culture. PCR is faster but more expensive than microbiological culture (KEID, 2006).

\section{Viral vaginitis}

In puppies, the first clinical signs of viral vaginitis present nonspecifically as apathy, anorexia, and persistent crying, leading to death within a few days (OLIVEIRA et al., 2009).

Infected adult animals are usually asymptomatic, as the virus remains latent in the body and can be reactivated when host immunity is compromised by stressful situations such as pregnancy and immunosuppressive therapy, making the animal a carrier and disseminator of the virus (COMERCIO, 2004). Clinical signs may appear as diffuse papulo-vesicular lesions on the vaginal mucosa (SCHAEFERS-OKKENS, 1996; VERSTEGEN; DHALIWAL; VERSTEGEN-ONCLIN, 2008). A few days after infection, the lesions become firm, similar to lymphoid follicles, and they regress completely in 14-18 days (JOHNSTON; KUSTRITZ; OLSON, 2001).

Reproductive failure due to herpesvirus infection can also occur and is characterized by infertility due to early embryonic death before implantation, fetal resorption, abortion with expulsion of developed and ossified fetuses, stillbirths, underdeveloped newborns or neonatal death (JOHNSTON; KUSTRITZ; OLSON, 2001).

The diagnosis of viral vaginitis is obtained based on serology, where specific antibodies against 
herpesvirus are measured. It is worth mentioning that considerable titers are detectable only 2-3 weeks after infection or reactivation of the virus and then decrease; in a few months, they are no longer significant because the virus is poorly immunogenic and may enter latency (SCHAEFERS-OKKENS, 1996, VERSTEGEN; DHALIWAL; VERSTEGENONCLIN, 2008).

It is also possible to isolate the virus from the infected tissues of adult hosts, such as the oral cavity and the genital and upper respiratory tracts, but the sensitivity of this method is low (only 20\%). Performing PCR with samples taken from nasal or genital tissues can confirm infection (VERSTEGEN; DHALIWAL; VERSTEGEN-ONCLIN, 2008).

Additionally, the most common necropsy findings are hemorrhage in the renal cortex, hepatomegaly, splenomegaly and petechiae in the liver and pleura (OLIVEIRA et al., 2009).

\section{Treatment}

\section{Vaginitis by Brucella canis}

As canine brucellosis has zoonotic potential, treatment is discouraged. However, the treatment of animals with high emotional value may be indicated and takes the form of castration, prolonged antibiotic therapy and rigorous serological monitoring (MEGID et al., 2002).

Various antimicrobial agents have been tested for their efficacy in vitro against Brucella spp., and susceptibility has been demonstrated for tetracyclines, chloramphenicol, aminoglycosides, third generation cephalosporins and quinolones. However, a single course of therapy with a single drug has not shown clinical efficacy in vivo; the best results are obtained with longer treatments with antibiotics including tetracyclines and streptomycin Canine brucellosis is commonly introduced in commercial kennels through infected animals or by newly acquired semen. This disease can be controlled with good hygiene practices because
B. canis is sensitive to various disinfectants like hypochlorite and $70 \%$ alcohol. It is important to perform periodic serological evaluation, to quarantine new animals and to discard seropositive animals. These actions are important because there is no vaccine for B. canis (CFSPH, 2009).

\section{Viral vaginitis}

There is no effective treatment, but viral vaginitis is fortunately self-limiting (PURSWELL, 2004). To prevent herpesvirus infection, we must focus on prevention, with actions like local hygiene, good nutrition and local heating because herpesvirus is adapted to lower temperatures (PURSWELL, 2004; VERSTEGEN; DHALIWAL; VERSTEGENONCLIN, 2008).

For immunization, it is recommended that females are vaccinated a month before estrous, with a booster dose administered during mating if the animal does not express antibody titers greater than $1: 128$. A third dose is applied during the second half of pregnancy, and the antibodies are subsequently passed to offspring via the colostrum. This protocol is used in Europe and the United States (VERSTEGEN; DHALIWAL; VERSTEGENONCLIN, 2008).

In severe cases, intraperitoneal inoculation of 1-5 $\mathrm{ml}$ of plasma from hyper-immunized animals and Acyclovir, a guanosine analog that interrupts viral replication by inhibition of DNA polymerase may be used (VERSTEGEN; DHALIWAL; VERSTEGEN-ONCLIN, 2008). Brazil does not have a vaccine available on the market yet.

\section{Characteristics of Vaginitis Based on Age of Bitch}

Juvenile vaginitis

\section{Etiology}

Juvenile vaginitis comprises $40-52 \%$ of reported cases of vaginitis. Affected animals usually do not 
demonstrate systemic involvement (JOHNSTON; KUSTRITZ; OLSON, 2001).

Immaturity of the reproductive physiology and immune system predisposes young animals to inflammation and/or vaginal infections (PURSWELL, 2004).

\section{Clinical signs and diagnosis}

For neonates, the severe clinical status and poor prognosis are attributed to low body temperature (which favors viral replication), an immature immune system and a lack of maternal antibodies transmitted via the colostrum (CARMICHAEL; GREENE, 2006).

Juvenile vaginitis occurs in prepubertal females and is characterized by mucous or mucopurulent vulvar discharge, and systemic involvement is usually absent (PURSWELL, 2004). In most cases, the disease is self-limiting (PURSWELL, 2004; JOHNSON, 2009).

The diagnosis is made based on suspected etiology. Culture of vaginal secretions from these animals generally does not show significant bacterial growth (JOHNSTON; KUSTRITZ; OLSON, 2001).

\section{Treatment}

As the vaginal secretions do not show significant bacterial contamination, the use of antibiotics is contraindicated (JOHNSTON; KUSTRITZ; OLSON, 2001).

Some authors do not recommend the castration of animals affected by this disease before the first estrous or until clinical signs have been resolved because some bitches with prepubescent vaginitis heal spontaneously when they enter proestrus/ estrous. However, the relationship of castration or the estrous cycle to the incidence of vaginitis in young bitches needs to be further elucidated (PURSWELL, 2004; JOHNSON, 2009).
According to Tilley and Smith (2007), inducing pharmacological estrous in juvenile females with severe or chronic vaginitis that have been castrated may be advantageous. For this purpose, oral administration of diethylstilbestrol every 24 hours for seven consecutive days is recommended. Additionally, the treatment should be continued for two days after the onset of bleeding. However, this treatment may not resolve the disease, and the use of estrogen can result in significant side effects such as bone marrow aplasia, diabetes mellitus and thromboembolic disorders, which can be fatal to dogs (TILLEY; SMITH, 2007).

\section{Vaginitis in Adult Bitches}

\section{Etiology}

In adult animals, approximately $70 \%$ of vaginitis is secondary to predisposing causes or to a decrease of estrogen in castrated females (JOHNSTON; KUSTRITZ; OLSON, 2001; JOHNSON, 2009).

Anatomical abnormalities of the reproductive tract are identified in $35 \%$ of adult females with vaginitis, and the most common of these abnormalities are vulvar anomalies, hypertrophy of the clitoris, vaginal stenosis derived from longitudinal or transverse bands of connective tissue in the vagina or vaginal atresia (JOHNSON, 2009).

Vaginitis can be caused by factors that result in accumulation of urine or discharge from the vagina, such as stenosis of the vaginal vestibule junction, which can be identified by digital touch and requires treatment by digital dilatation or vaginectomy for correction in severe and recurrent cases (PURSWELL, 2004). The accumulation of urine in the vaginal vestibule may be caused by urinary incontinence, common in cases of ectopic ureters, hypoestrogenism (PURSWELL, 2004; TILLEY; SMITH, 2007), recto-vaginal fistulas or by other congenital problems in the reproductive system (JOHNSON, 2009). The normal flow of urine and vaginal secretions may also be disrupted 
by foreign bodies, granulomas and neoplasms, especially those due to transmissible venereal tumors and leiomyomas (PURSWELL, 2004; TILLEY; SMITH, 2007).

\section{Clinical signs and diagnosis}

The clinical signs vary depending on the etiology. However, approximately $30 \%$ of bitches with vaginitis do not have any clinical signs, and healing is spontaneous in $73 \%$ of cases, although this may take months or years (JOHNSON, 1991; JOHNSTON; KUSTRITZ; OLSON, 2001).

The cytology samples collected from adult dogs are more often septic in nature than samples from animals with prepubertal vaginitis, and approximately $80 \%$ of cultures showed bacterial growth (JOHNSTON; KUSTRITZ; OLSON, 2001).

\section{Treatment}

The key to overcoming vaginitis is to identify and correct the anatomical abnormalities and predisposing factors (SODERBERG, 1986; JOHNSON, 1991; JOHNSTON; KUSTRITZ; OLSON, 2001; JOHNSON, 2009; MUSHTAQ, 2008).

In adult bitches, the use of antibiotics for one month is recommended, and these are selected by culture and sensitivity tests of vaginal specimens. If the discharge is cytologically purulent or the animal displays excessive discomfort, as shown by frequent licking of the vagina, it is recommended to wash the perivulvar area to prevent spread of the infection to adjacent areas (JOHNSTON; KUSTRITZ; OLSON, 2001).

The use of antibiotics is recommended in animals whose vaginal cultures have demonstrated significant growth of a single bacterial species and also in animals with infections present in other systems, such as the urinary tract. However, recurrence is frequent if abnormalities and predisposing factors are not corrected (JOHNSTON; KUSTRITZ; OLSON, 2001; JOHNSON, 2009).

Drugs like ampicillin, amoxicillin and clavulanate, trimethoprim-sulphonamide, enrofloxacin and cephalosporins are generally effective against gram-positive and gram-negative microorganisms of the genitourinary tract. Tetracycline and chloramphenicol are effective against gram-negative pathogens (JOHNSON, 2009).

Cleansing of the vagina can be helpful in the removal of accumulated secretions. For this purpose, $0.05 \%$ chlorhexidine, $0.5 \%$ povidone-iodine or $0.2 \%$ nitrofurazone can be used twice daily until the discharge is reduced. The use of saline solution four to six times a day can also help to remove the vaginal secretions. Additionally, the administration of vitamin $\mathrm{C}$ helps to control infections by acidifying the local secretions (TILLEY; SMITH, 2007).

Surgical treatment is recommended for the correction of anatomic abnormalities, removal of foreign bodies or extirpation of tumors. Vaginectomy can be performed as a last resort in patients which are refractory to medical treatment (TILLEY; SMITH, 2007).

\section{Final Considerations}

Canine vaginitis needs to be further studied and understood to assist the clinician in the identification and resolution of triggering factors because relapses of the disease are frequent when no correction is performed.

The use of vaginal secretion cultures usually cannot define the etiologic agent of vaginitis because the presence of resident microbial growth makes it difficult to determine if bacteria caused the disease. However, the isolation of some bacteria that are known to cause reproductive damage is of great importance for breeding animals. The use of an antibiogram is useful to select the best antibiotic to be used, if necessary. 
Determining the primary cause of vaginitis can be challenging, as routine laboratory tests are often not enlightening. The best tools are a wellconducted clinical examination, vaginal inspection by digital vaginoscopy and serological screening for infectious agents such as canine herpesvirus and Brucella canis. These are primary agents that may be associated with vaginitis and reproductive problems such as infertility and miscarriage.

\section{References}

ALMEIDA, A. C.; SANTORELLI, A.; BRUZADELLI, R. M. Z.; OLIVEIRA, M. M. N. F. Seroepidemiology of canine brucellosis caused by Brucella canis and Brucella abortus in the city of Alfenas, MG. Brazilian Archive of Veterinary Medicine and Animal Science, v. 56, n. 2, p. 275-275. 2004.

AVILA, M. O.; CAMARGO, L. M.; BENETTI, A. H.; ALARCON, L. F. Vaginal mucosal microbiota of healthy female canine clinically served at the veterinary Hospital of Cuiabá's University, MT. In: BRAZILIAN CONGRESS OF VETERINARY MEDICINE, 35., 2008, Grasslands. Proceedings... Grasslands: Conbravet, 2008. unpaged.

BROWN, C. M.; PIETZ, D. E.; RANGER, C. R. Experimental Brucella canis infection in the dog. In: WORLD VETERINARY CONGRESS, 20., 1975, Thessaloniki. Proceedings...Thessaloniki: WSAVA, 1975. p. 1795-1800.

CARMICHAEL, L. E.; GREENE, C. E. Canine herpesvirus. In: GREENE, C. E. Infectious diseases of the dog and cat. $2^{\text {nd }}$ ed. Philadelphia: W.B. Saunders, 2006. p. 47-53.

CENTER FOR SECURITY \& PUBLIC HEALTH CFSPH. Canine brucellosis: Brucella canis contagious abortion, undulant fever. CFSPH, 2009. july. Available at: $<$ http//www.cfsph.iastate.edu $>$. Accessed at: 13 june 2011.

COMERCIO, E. A. Canine herpes virus as a cause of abortion and neonatal death. In: GOBELLO, C. Topics of breeding dogs and cats by Latin American authors. Argentina: Grafica Latina S. A., 2004. chap. 21, p. 229231.

DAHLBOM, M.; JOHNSSON, M.; MYLLYS, V.; TAPONEN, M. J.; ANDERSSON, M. Seroprevalence of canine herpesvirus-1 and brucella canis in finnish breeding kennels with and without reproductive problems. Reproduction in Domestic Animals, n. 44, n. 1, p. 128-131, 2009.

FELDMAN, E. C.; NELSON, R. W. Vaginal defects, vaginits, and vaginal infection. In: _. Canine and feline endocrinology and reproduction. $2^{\text {nd }}$ ed. Philadelphia: W.B. Saunders Company, 1996. chap. 26, p. 661-663.

GREENE, C. E.; CARMICHAEL, L. E. Canine brucellosis. In: GREENE, C. E. Infectious diseases of the dog and cat. 3 . $^{\text {rd }}$ ed. Philadelphia: Elsevier Inc, 2006. chap. 40 , p. 369-380.

HAFEZ, E.; HAFEZ, E. S. E. Female reproduction anatomy. In: . Animal reproduction. $7^{\text {th }}$ ed. São Paulo: Manole, 2004. chap. 2, p. 27-28.

HASHIMOTO, V. Y.; ANZAI, E. K.; GALHARDO, J. A.; DIAS, J. A.; GIORDANO, G. P.; PRETTO, L. G.; FREITAS, J. C. Bacterial agents isolated from bitches with vaginitis. In: ANNUAL MEETING OF SCIENTIFIC INITIATION, 11., 2002, Maringá. Proceedings... Maringá: Maringá State University, 2002. unpaged.

HOLLETT, R. B. Canine brucelosis: Outbreaks and compliance. Theriogenology, Philadelphia, v. 66, n. 3, p. 575-587, 2006.

JOHNSON, C. A. Diagnosis and treatment of chronic vaginitis in the bitch. The Veterinary Clinics of North America. Small Animal Practice, Charleston, v. 21, n. 3, p. 523-531, 1991.

. Disorders of the vagina and uterus. In: NELSON, R. W.; COUTO, C. G. Small Animal Internal Medicine. $4^{\text {th }}$ ed. Rio de Janeiro: Elsivier, 2009. chap. 57, p. 911926.

JOHNSTON, S. D.; KUSTRITZ, M. V. R.; OLSON, P. N. S. Disorders of the canine vagina, vestibule and vulva. In: Canine and fline therioegenology. Philadelphia: WB Saunders, 2001. cap. 12, p. 235-237.

KEID, L. B. Evaluation of direct and indirect methods of diagnosis of brucellosis in naturally infected dogs. 2006. Thesis (PhD of Veterinary Medicine) - Faculty of Veterinary Medicine,.São Paulo's University, São Paulo.

KEID, L. B.; SOARES, R. M.; MORAES, Z. M.; RICHTZENHAIN, L. J.; VASCONCELLOS, S. A. Brucella spp. Isolation from dogs from commercial breeding kennels in São Paulo estate, Brazil. Brazilian Journal of Microbiology, v. 35, p. 161-166, 2004.

LARSSON, M. H. M. A. Agglutinins against Brucella canis searches in human sera in the city of São Paulo, Brazil. Journal of Public Health, São Paulo, v. 14, p. 404-407, 1980. 
MEGID, J.; RIBEIRO, M. G.; MORAES, C. C. G.; NARDI JÚNIOR, G.; PAES, A. C.; PRESTES, N. C.; LISTONE, F. J. P.; Canine brucellosis - A case report. Biological Institute's Archives, São Paulo, v. 69, n. 4, p. 103-106, 2002.

MORAES, C. C.; MEGID, J.; SOUZA, L. C.; CROCCI, A. J. Canine brucellosis prevalence in the microregion of the Serra of Botucatu, São Paulo, Brazil. Biological Institute's Archives, v. 69, n. 2, p. 7- 10, 2002.

MUSHTAQ, A. M. Reproductive diseases of the female small animal. In: FRAZER, C. M. Manual merck de veterinária. 9. ed. New Jersey: Merck \& Co., Inc., 2008. Available at: <http://www.merckvetmanual.com/ mvm/ index.jsp?cfile $=\mathrm{htm} / \mathrm{bc} / 112012 . \mathrm{htm}$. $>$. Accessed at: 29 set. 2010.

NOTHLING, J. O.; HUSSI, D.; STECKLER, D.; ACKERMANN, M. Seroprevalence of canine herpesvirus in breeding kennels in the Gauteng Province of South Africa. Theriogenology, Philadelphia, v. 69, p. 276-282, 2008.

OLIVEIRA, E. C.; SONN, L.; BEZERRA, P. S. J.; TEIXEIRA, E. M.; DEZENGRINI, R.; PAVARINI, S. P.; FLORES, E. F.; DRIEMEIER, D. Clinical and pathological findings in dogs naturally infected by herpesviruses canino1. Brazilian Veterinary Research, v. 29, n. 8, p. 637-642, 2009.

PESSEGUEIRO, P.; BARATA, C.; CORREIA, J. Brucellosis - a systematic review. Internal Medicine, v. 10, n. 2, p. 91-100, 2003.

PURSWELL, B. J.; Vaginal disorders. In: ETTINGER, S. J.; FELDMAN, E. C. Textbook of veterinary internal medicine. $6^{\text {th }}$ ed. Philadelphia: Elsevier Saunders, 2004. v. 2 , chap. 253 , p. 1686-1690.

QUINN, P. J.; MARKEY, B. K.; CARTER, M. E.; DONNELLY, W. J.; LEONARD, F. C. Veterinary microbiology and microbial disease. $4^{\text {th }}$. ed. Oxford: Blackwell Science, 2004. chap. 28, p. 162-167.
READING, M. J.; FIELD, H. J. A serological study of canine herpes virus-1 infection in the english dog population. Archives of Virology, v. 143, n. 8, p. 14771488, 1998.

RONSEE, V.; VERSTEGEN, J.; ONCLIN, K.; FARNIR, F.; POULET, H. Risk factors and reproductive disorders associated with canine herpesvirus-1 (CHV-1). Teriogenology, Amsterdam, v. 61, n. 4, p. 619-636, 2004.

SCHAEFERS-OKKENS, A. C. Fertility disorders with an infections etiology. In: RIJNBERK, A. Clinical endocrinology of dogs and cats: an illustrated text. The Netherlands: Kluwer Academic Publishers, 1996. chap. 7, p. 153-154.

SILVA, L. D. M; SILVA, A. R.; CARDOSO, R. C. S. Artificial insemination in dogs. In: GONÇALVES, P. B. D.; FIGUEIREDO, J. R.; FREITAS, V. J. F. Biotechnology applied to animal reproduction. $2^{\text {nd }} \mathrm{ed}$. São Paulo: Varela, 2002. Cap. 5, p. 73-74.

SODERBERG, S. F. Vaginal disorders. The Veterinary Clinics of North America. Small Animal Pratice, Charleston, v. 16, n. 3, p. 543-559, 1986.

SPINOLA, A. G.; COSTA, M. D. M. Human brucellosis in workers of a slaughterhouse in the city of Salvador, Bahia, Brazil. Journal of Public Health; São Paulo. v. 6, n. 2, p. 157-165, 1972.

TILLEY, L. P.; SMITH, F. W. K. Vaginitis. In: Blackwell's five-minute veterinary consult: canine and feline. $4^{\text {th }}$ ed. Iowa: Blackwell, 2007, p. 1406-1407.

VERSTEGEN, J.; DHALIWAL, G.; VERSTEGENONCLIN, K. Canine and feline pregnancy loss due to viral and non-infectious causes: a review. Theriogenology, Philadelphia, v. 70, n. 3, p. 304-319, 2008. 
